\title{
It's not about eating
}

\author{
Alden H. Harken, MD, FACS \\ From the Department of Surgery, University of California, Oakland, Calif. \\ Disclosures: Author has nothing to disclose with regard to commercial support. \\ Received for publication Feb 22, 2017; accepted for publication March 3, 2017; available ahead of print April 1, \\ 2017. \\ Address for reprints: Alden H. Harken, MD, FACS, Department of Surgery, University of California, San \\ Francisco-East Bay, 1411 E. 31st St (QIC 22134), Oakland, CA 94602 (E-mail: alden.harken@ucsfmedctr. \\ org). \\ J Thorac Cardiovasc Surg 2017; 154:989 \\ $0022-5223 / \$ 36.00$ \\ Copyright (C) 2017 by The American Association for Thoracic Surgery \\ http://dx.doi.org/10.1016/j.jtcvs.2017.03.019
}

The 2016 Nobel Prize in Medicine was awarded to Yoshinori Ohsumi of the Tokyo Institute of Technology for the description of the genes that control the orderly degradation and recycling of cellular building blocks in an evolutionarily conserved process termed "autophagy." Cellular machinery that can tear down and rebuild cellular materials might intuitively exert formidable control over cellular phenotype. Indeed, starvation-induced autophagy was recognized early as a cell survival strategy. During the past decade, however, dysfunctional autophagy has been linked to a huge spectrum of diseases, including cancer, neurodegenerative disorders, and immunoincompetence. Like most cellular programs, healthy autophagy can sustain a cell as young and happy, but autophagy gone rogue is bad. The inciting signal common to autophagy appears to be cellular stress. The twin enemies of the cardiovascular surgeon are thrombosis and bleeding. Whether it be formed blood elements activated by a cardiopulmonary bypass machine or a balloon catheter raked across a defenseless endothelial cell, our patient's endovasculature is the line of defense that experiences the first assault. In the accompanying series of studies by Yau and colleagues, ${ }^{1}$ the authors postulate that endothelial cell autophagy might influence the prothrombotic or antithrombotic manner in which that cell responds to stressors relevant to the cardiovascular surgeon.

Yau and colleagues ${ }^{1}$ generated mice in which the essential endothelial cell autophagy gene was silenced. They then documented delayed carotid and mesenteric artery

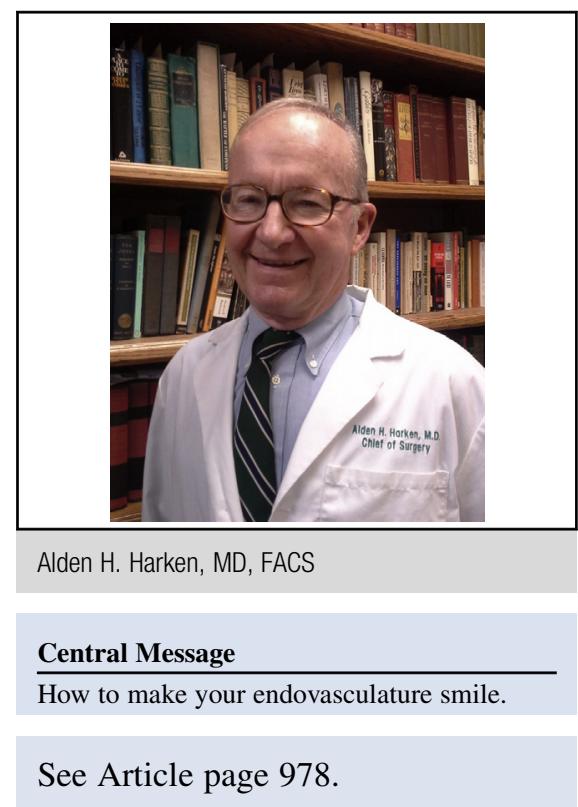

occlusion after a thrombotic stimulus and similarly recorded decreased thrombus generation after laser injury of arterioles in these genetically altered mice. Then, using human umbilical vein endothelial cells, they tracked the mechanism by documenting a reduction in the inflammatory tumor necrosis factor signal, resulting in an attenuated tissue factor message, leading to less clot. So, at first blush, for the cardiovascular surgeon, vigorous endothelial cell autophagy may be bad.

The authors have persuasively identified a molecularlevel target (the Autophagy-Related 7 gene) that will be further interrogated and likely transform thoracic and cardiovascular surgery into an even safer medical discipline.

\section{Reference}

1. Yau JW, Singh KK, Hou Y, Lei X, Ramadan A, Quan A, et al. Endothelial-specific deletion of autophagy-related 7 (ATG7) attenuates arterial thrombosis in mice. J Thorac Cardiovasc Surg. 2017;154:978-88.e1. 